\title{
The Study of Forest Entomology in India.
}

$\mathrm{T}^{\mathrm{H}}$ HIRTY years ago the entomology of the forests of India and its study were still a closed book. Types of forest insects had found their way into the national museums and private collections in Europe, and thus received a name. But, as became apparent during the first decade of the present century, numbers of the insects of forest importance, as probable or possible pests, were unnamed and their biology unknown. The early pioneer work of the forest officers who were first set to grapple with the position proved by no means easy, but extraordinarily fascinating.

In India, during those first few years, the assistance of a dozen or two expert systematists was required to enable progress to be made at all, and the preliminary publications of results (expected by and demanded by Government) to be issued.

The Indian F'orest Records, parts 9 and 10 (Calcutta : Government of India Printing Office, 1930), afford a typical example of this progress. Both these parts are devoted to the genus $X$ yleborus, a genus of wood borers (the so-called pinhole and shothole borers) well known to foresters. In part 9, Hans Eggers, of Stolberg, Harz, Germany, discusses "Neue Xyleborus Arten (Col. Scolytidæ) aus Indien ". In this paper the author describes some forty new Indian forest species, and also proposes a new genus, Pseudoxyleborus, in which he describes one species, $P$. Beesoni.

Part 10 of the I.F. Records is written by Dr. C. F. C. Beeson, forest entomologist at the Dehra Dun Research Institute, and is entitled "The Biology of the Genus Xyleborus, with more New Species". Chap. i. is devoted to the new species, and is indicative of the valuable knowledge we now possess upon this important genus.

Chap. ii. is devoted to the main theme. "The present Record", the author says, "summarises the available biological information on Indian species of Xyleborus, their regional distribution, food plants, life histories, and gallery patterns." The importance attached to the systematic study of groups of pests of this type, if solely from the economic point of view, will become evident from the following remarks: "Pinholes and shotholes in timber in India are made by a specialised group of borers (often called 'ambrosia beetles ') comprising the extensive genus Xyleborus, as also Webbia of the family Scolytidæ, and Crossotarsus, Diapus, and Platypus of the family Platypodidæ. The term 'pinhole' is applied to holes the size of a pinprick and 'shothole' to holes corresponding in size to various small shot up to $3 \mathrm{~mm}$. in diameter; otherwise there is no funda- mental difference in the mode of origin of the holes or in the habits of the borers in making them. The tunnels are bored in wood by the female beetle, and the wood-dust resulting from their excavation is thrown outside, so that a free space is provided in which eggs are laid and the larval breed is reared to maturity. Unlike the majority of borers of timber, the larvæ of ambrosia beetles do not feed on wood, but on fungus (the ambrosia) that grows on the walls of the tunnel in a mycelial layer of variable thickness and produces highly nutritious fruiting bodies. Tunnels that have been occupied for a short time get stained black, and in some species secondary saprophytic fungi develop, that discolour the wood vessels for a little distance around the tunnel. Timber that has been attacked by pinhole and shothole borers thus shows defects in the form of black spots and lines on the sawn surfaces, which spoil it for ornamental purposes and for special uses as matches, veneer, plywood, etc. ; unless heavily attacked, it is not seriously weakened for structural purposes."

The paper ends with an excellent index to food plants of Indian species of Xyleborus. The author is to be congratulated upon an excellent piece of work.

Of a different type, emanating from the same research branch at Dehra Dun, is the series of papers dealing with the immature stages of the Indian Coleoptera, by Mr. J. C. M. Gardner (I.F. Records, Entom. Ser., vol. 16, part 3, 1931). Mr. Gardner produces his eighth paper," Cerambycidae (Continued)", which completes the description of the identified material in the Dehra Dun collections. The classification of the family Cerambycidæ, and, says the author, "especially of the sub-family Laminæ, has always presented difficulties to workers, who have relied almost entirely on the external morphology of the adult; the study of immature stages should help in a more satisfactory phylogenetic grouping of genera. So far, attention has been concentrated on larvæ, but the pupal stage certainly deserves more attention than it has received."

That Indian research work should be giving what might almost be termed a lead in a branch of study which may prove of considerable practical importance, would seem to merit being placed on record. Certainly, Mr. Gardner's admirable and patient work should enable the forest officer out in the forest, or in the temporary timber depot, to recognise a pest, abundantly represented by the larvæ in the timber but with no trace of the perfect insect; a position only too well known to many forest officers.

\section{Palæolithic Flint Implements.}

IN the course of the work in southern Palestine of 1 the British School of Archæology in Egypt, a large number of palæolithic implements of early type have been collected near Gaza. A number of these were exhibited at a meeting of the Royal Anthropological Institute about two years ago by Sir Flinders Petrie, and it was then determined to submit them to Mr. Reid Moir for inspection and report.

In making his report, which is published in the Institute's Journal (vol. 60, pt. 2), Mr. Reid Moir finds that the implements fall into two clearly defined groups. The first consists of massive specimens, produced by the removal of thick wide flakes, and much abraded : the second is formed by the detachment of thin flakes tending to be of greater length than width, for the most part showing no sign of abrasion and clearly the product of a different technique. The difference in morphology is fundamental. Mr. Reid Moir considers that the first group belongs to the series worked out for East Anglia by him, which exhibits the transition from the rostro-carinate to the earliest palæolithic hand-axe. Rostro-carinates and transitional forms have been found in Uganda, Rhodesia, India, and now Palestine. Notwithstanding the fact that the Palestine implements have not been found in any ancient deposit, Mr. Reid Moir is still inclined to assign them to the early Pleistocene. The second group is classified as Acheulean, comparable with Acheulean implements of the second inter-glacial in East Anglia.

This conclusion raises the question, as Mr. Reid Moir puts it, "how to account for the presence in

No. 3235, VoL. 128] 